\title{
ICUにおけるせん妄についての苦悩を表出した心臓外科患者 の一症例
}

江杘 晴美

\begin{abstract}
要約：せん妄は, 身体的原因により短期間に発現して時間とともに変動する, 注意力や意識 レベルの障害と睡眠覚醒障害を伴った認知機能の変化である。今回, ICU滞在中にせん妄を 発症した患者において，その後，せん妄に対する患者の思いを直接聞くことができたので報 告する。症例は, 60 歳代前半の男性。修正大血管転位症のため左側房室弁置換術, 心房細動 根治術を受け, 術後2 日目よりせん妄を発症した。悲観的, 抵抗・拒絶, 見当識障害が認めら れたが，家族が介入すると現実認知が可能であった。術後 8 日目，「大変見苦しいところをお 見せして申し訳ありませんでした」と涙を流した。このときの患者の言動から, 見当識障害, 会話の障害など，せん妄患者によく認められる現象が患者にとって苦痛で辛いものであるこ とがわかった。看護スタッフはその気持ちを理解して援助する必要性が示唆された。
\end{abstract}

Key words: (1) delirium, (2) distress, (3) nursing

\section{はじめに}

せん妄は, 身体的原因により短期間に発現して時間 とともに変動する, 注意力や意識レベルの障害と睡眠 覚醒障害を伴った認知機能の変化である1) 5)。せん 妄のタイプには, (1)興奮, 不安定・不安, チューブ類 を引っ張る, 高揚感などを呈する活動過剩型, (2)引き こもり・自閉, 感情表現の欠如, 無感動・無関心, 倦 㤐感, 脱力感, 反応低下, 傾眠などを呈する活動低下型, あるいは, (3)これらの混合型があるといわれている。 一過性かつ可逆性であることが多く, 発症時期は, 手 術・受傷直後, 麻酔覚醒時, 手術・受傷から数日を経 過した後などがある11,6)。

せん妄に関する研究は, 患者の体験や幻覚などの内 容の記述7) 10), 尺度開発11) 16), 要因の探索 ${ }^{17) ~ 19), ~}$ 介入研究4),5) な゙が多く, 患者自身がせん妄を起こし たことを,どのように思っているのかについて書かれ ているものはない。せん妄の予防が未だ不可能である 現在, せん妄を発症している患者や発症した患者の思 いにも着目する必要がある。すなわち, 患者の思いの
中に, 言葉が出なかったときの辛さや, せん妄を発症 したことへの恥ずかしさがあり，さらに，患者自身が これらを医療者や家族に対して表現できないなど，苦 悩となる内容が含まれているとすると, 患者の重荷と なり尊厳が脅かされかねない。そのため, 看護師はせ ん妄を発症している，あるいは発症した患者の思いを 重視し, 援助を行う必要があるのではないかと考える。 今回, ICU滞在中にせん妄を発症した患者の, その後 の思いを直接聞くことができたので報告する。

\section{症 例}

患者：60歳代前半の男性。

現病歴：修正大血管転位症, 左側房室弁閉鎖不全 (先天性心疾患のため僧帽弁, 大動脈弁という名称は 使用しない), 心房細動で初回入院。その後, 頻脈性心 房細動及び心不全のために入院を繰り返していた。今 回, 心不全症状があり内科的治療を試みたが改善せず, 心臓カテーテル検査の結果, 手術適応となり入院と なった。入院時より,メチルジゴキシン, フマル酸ビ ソプロロール, スピロノラクトン, フロセミド, ワル 
ファリンカリウム, エチゾラムの内服治療が開始され た。15年前から禁煙しており, アルコールも摂取しな い。手術前にはインターネットで疾患について調べ, 家族とともにセカンドオピニオンを希望していた。ま た, 看護師, 看護学生・教員に自身について積極的に 話をすることが多かった。医師に対しては, 一般病院 での手術に大学病院の医師を呼んで欲しいなどの要望 があった。

術前の心エコーでは, 駆出率 (ejection fraction, EF) $47 \%$, 左室拡張終期径 (left ventricular end-diastolic dimension, LVEDD) $69 \mathrm{~mm}$, 左側房室弁に高度の閉 鎖不全, 右側房室弁に中等度の閉鎖不全が認められた。 手術は左側房室弁置換術, 心房細動根治術が行われた。 前投薬はなく, 麻酔は酸素 - 空気 - プロポフォール (oxygen-air-propofol, OAP) 群で行われ, クエン酸フェ ンタニル, ミダゾラム, 臭化ベクロニウムが使用され た。手術時間 418 分 (6 時間58分), 体外循環 183 分, 大動脈遮断70分, 出血量 $1,487 \mathrm{~g}$, 術中尿量 $2,569 \mathrm{ml}$, 赤血球濃厚液 2 単位と新鮮凍結血漿 10 単位を輸血, 術 中水分バランスは $+1,700 \mathrm{ml}$ であった。

気管挿管チューブ, 中心静脈ライン, 動脈圧ライン, 一時的ペースメーカー, 膀胱留置カテーテル, 未梢静 脈ラインが挿入され, 心豪・胸骨下にドレーンが留置 された。なお, 肺動脈カテーテルは挿入困難であり, 扦入されなかった。

ICUでの術後経過 : 術後, 気管挿管したままICUへ 入室した。入室時, 血圧は $110 / 70 \mathrm{mmHg}$, 心拍数 90 回・ $\min ^{-1}$, ペーシング設定AAI 60 回・ $\min ^{-1}$ であっ た。塩酸ドパミン $5 \mu \mathrm{g} \cdot \mathrm{kg}^{-1} \cdot \mathrm{min}^{-1}$, 塩酸ドブタ ミン $5 \mu \mathrm{g} \cdot \mathrm{kg}^{-1} \cdot \mathrm{min}^{-1}$, カルペリチド, ニトログ リセリンが持続投与され, 塩酸デクスメデトミジンに て鎮静が行われた。ICU入室後, 収縮期血圧が70 $\mathrm{mmHg}$ 台に低下したため, 人血清アルブミンが投与さ れ, ペーシング設定が 90 回・ $\min ^{-1}$ に変更された。 その後も収縮期血圧は上昇せず,ノルエピネフリン $0.03 \mu \mathrm{g} \cdot \mathrm{kg}^{-1} \cdot \mathrm{min}^{-1}$ が開始され, 収縮期血圧は $100 \mathrm{mmHg}$ 台へ上昇した。心拍はオールペーシング で, 心室性期外収縮が $1 \sim 3$ 回・ $\min ^{-1}$ 認められた。 血液一般検査において Hb $9.8 \mathrm{~g} \cdot \mathrm{d} l$-1であったため, 赤血球濃厚液 2 単位が輸血された。

術後1日目, 収縮期血圧は $100 \mathrm{mmHg}$ 前後で安定して おり，ノルエピネフリン投与は中止された。心拍はオー ルペーシングで, 心室性期外収縮が $0 \sim 2$ 回・ $\min ^{-1}$ 認め られた。気管挿管チューブが抜管され, 抜管後の自力喀 痰は良好であった。安静度は座位が許可され, 胃管抜 去後に看護師の促しで座位になり, 飲水した。しかし,
同日夜間からせん妄症状が出現し,「おれはもう死ん だ。家族に伝えてくれ。ここはお棺の中だ」「お前を 憎む，俺を殺したから。麻酔はやめろと言っただろ」 など興奮気味であった。看護師の説明ですぐに落ち着 いたが, 熟睡した様子はなかった。夜間は血行動態に 大きな変化はなく経過した。

術後 2 日目, ペーシングが中止され, 心拍数 100 回・ $\mathrm{min}^{-1}$, 収縮期血圧 $120 \mathrm{mmHg}$ 前後で安定し, 塩酸ド パミン及び塩酸ドブタミンが減量された。患者は, 理 学療法士による心臓リハビリテーション時に端座位に なったが, それ以外はベッド上座位で過ごした。患者 の表情は硬く,「おれはもうだめだ」「元気ない。もう

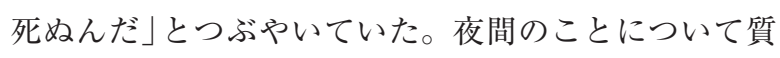
問すると,「全然眠れん。だめだ, 眠くない」と強い口 調で返答した。内服が開始され, 看護師が与薬しょう とすると「いやだ」と強く拒否した。内服の必要性を 話し, 口へ薬を運んだが, 飲み込もうとせず吐き出し てしまった。患者に理由を問うが, 無言で何も答えな かった。その後, 看護師が再度必要性と薬効を説明し, 患者は了解し内服した。また,「麻酔の先生が来て麻 酔を打たれる」「注射に麻酔を入れただろ」と注射や 点滴に対して敏感で, 看護師の動きを目で追い, 看護 師が点滴の横に行くと「やめろ」などの発言があった。 採血も拒否し, 看護師が必要性を説明したが, 強く拒 んだ。患者は, 看護師と自宅にいる娘を見間違えたの か, 名前を呼んだり「(そこに)いるから呼んでこい」 と看護学生に繰り返し言ったりした。看護師が家族に 連絡し, 患者と面会してもらい, 採血する際に麻酔な どを入れるのではなく, 血液採取のみ行うことを両者 に約束した。そして, 家族に確認のために監視しても らいながら採血を行った。患者は, 家族に対しても「も う心臓はだめだ」などと訴えていた。

日付がよくわからなくなっている様子もあったた め, 看護師と看護学生がカレンダーを用いて入院・手 術日などの説明を行った。看護学生が職業や家族に関 する質問をすると問題なく受け答えができ, 表情も少 し穏やかになるが, しばらくすると悲観的・被害妄想 的な訴えが繰り返された。同日夕方, 体温 $38^{\circ} \mathrm{C}$, 心室 性期外収縮が $5 \sim 7$ 回・ $\min ^{-1}$ 認められ, 活気がなく セントラルモニターを充血した目で見つめていた。カ テーテル類を引っ張る, ベッドから降りようとするな どの危険行為は終日認められなかった。同日昼から食 事が開始されたが, 病院食には手をつけず, 家族が持 参したゼリーを少量と, 経口栄養剤をわずかに摂取し たのみであった。夜間は家族の付き添いがあったが, 患者は酸素マスクをはずすなど落ち着きがなかった。 
術後 3 日目朝方, 収縮期血圧は $110 \mathrm{mmHg}$, 心拍数 100 回・ $\mathrm{min}^{-1}$ 前後であった。患者はベッド上で落ち 着きなく行動しており, ショートランが出現した後に $\mathrm{R}$ on $\mathrm{T}$ が認められた。患者は強く拒否したが, 塩酸 リドカインが経静脈投与された。同日, 精神科医によ る診察があり，夜間の不眠に対してハロペリドールの 静脈注射の指示が出された。また, 同日ICUを退室し たが, 患者の表情は険しく, 内服や酸素マスク, 処置 に対する拒否が続いた。午後, 一般病棟で上室性頻拍 となり, ジゴキシンと塩酸ベラパミルが経静脈投与さ れた。夕方には心拍はやや安定したが, 患者は血圧や $\mathrm{SpO}_{2}$ などの測定を拒否し，酸素マスクも拒否した。 呼名には「うん」と反応はあるが, 表情は険しく一点を 見つめていた。家族が終日付き添ったが, 病院食は摂 取せず，家族が持参したものを少量摂取していた。入 眠前にハロペリドールを投与されたが，夜間は10〜 15分ごとに覚醒している様子であった。

術後4日目, 深夜は処置に対してやや拒否的であっ たが, ハロペリドールの使用で多少睡眠していた様子 であり，朝には表情が穏やかになった。患者自身から 「眠れた」との発言が聞かれ，内服・処置などに関する 拒否は認められなくなった。食事摂取量も徐々に増加 していった。心拍は終日安定していた。

術後5日目の朝は熟睡感があり, 日常生活動作を拡 大することができた。

術後8日目, 病棟の廊下で歩行中の患者に遭遇した。 回復を喜ぶ思いを伝えたところ, 患者は「大変見苦し いところを抄せして申し訳ありませんでした」と 言った。少し返事に困っていると，患者は「あのとき は, 夢を見ているようでした。夢なのか夢でないのか, わかりませんでした。本当に, 看護学生さんの大切な 勉強の場であるのに，あんな見苦しいところを打見せ して」と涙を浮かべた。そして,「本当に夢なのか, 夢 でないのかわからなくてね」と繰り返した。これに対 し，患者にねぎらいの言葉をかけ，決して䎵ずかしい ことではなく,たびたび起こり得ることであると伝え た。

\section{考 察}

本症例は, 術後ICUにおいて, 環境認識における 清明度の低下や, 見当識障害などを呈しており, Diagnostic and Statistical Manual of Mental Disorders (DSM)- $\mathbb{N}^{2)}$, International Classification of Diseases (ICD) $10^{3)}$ の診断基準からもせん妄を発症したと考 えられる。日本語版The Neelon and Champagne (NEECHAM) 混乱・錯乱状態スケール11)では中等度
〜重度の混乱・錯乱の状態にある。患者は悲観的であ $\eta$, 抵抗・拒絶や日時の混乱などの見当識障害が認め られ，家族の介入によってのみ現実認知が可能であっ た。ICU退室後, せん妄を起こしたことを覚えており, 患者の口ぶりや涙を浮か心゙たことから, せん妄の体験 がこの患者にとって非常に辛いものとなっていると考 えられる。これらは, ICU シンドローム患者へのイン タビューによる先行研究で見られた結果と共通点が多 い。

Granberg ら 7)は, ICUシンドロームを「非常にスト レスの多い環境で起こっている感情的変化の状態」と 定義し, 患者の体験をインタビューした。その結果か ら, ICUシンドロームの症状には「恐怖または恐怖で はない非現実的な経験」「日時・場所の認識の混乱」「話 す・考える・記憶・理解の障害もしくは困難」などが あることを明らかにした。その中で, 患者は抜管後に 覚醒を自覚するが, 日時がわからなくなり, 看護師か ら日時を教えてもらったが, 数分後には再び日時の認 知障害を自覚しており，時計を見ても時間の認識や記 憶が困難であったと報告している。また，ある患者は， 9 時の次が何時なのかを認識することが困難であった と報告している。この日時の混乱は, 本症例が体験し た日時の混乱と一致している。さらにこの研究では, 患者は時間に対する認識の障害を自覚しているが, 一 方でそれを恥じており，看護師に尋ねることができな かったとされている。本症例では, ICU退室後に自己 を恥じていることが表出されたものの, 内容までは確 認できなかった。しかし, 時間に対する認識の障害や, それを自覚していることを含んでいる可能性がある。

本症例では, 被害妄想的な訴えも多かった。患者は, 心臓が悪いために手術したことは認識できていたよう であるが, 夢と現実の区別がつかず, 悲観的で心理的 に危機的な状況に置かれていたと考えられる。また, 患者は麻酔薬に対して強い抵抗を示し, その結果, 必 要な投薬や採血が困難であった。これらの抵抗・拒絶 は, 最も認知能力の低い自己防衛的な行動であると解 釈することができる11)。つまり，せん妄を発症した ことで認知が強度に障害され, 看護師の言動に対して 猜疑心を抱き，自己防衛行動をとったと考えられる。 しかし，家族を認識することができ，家族が来院した ことで部分的に現実を認識している。これは, 家族に よって患者が現実を認知するという Granberg ら 7)の 報告と一致している。

せん妄予防のためのケアには, ハイリスク患者の予 測, 具体的で現実的な情報提供, 生活リズムの安定化 と現害的生活感覚の維持, 苦痛緩和と安心感を与える 
ことなどが挙げられ 20), 発症した場合のケアでは, 転 倒・転落予防, 輸液経路の確保, 鎮静, 根気よく患者 に伝えるコミュニケーション, 安心感を与える対応, 睡眠の確保と昼夜の区別, 家族に対するケアが挙げら れている20)。

しかし, 看護師に安心感や安寧を感じている患者が いる一方, 孤独感・孤立感・疎外感を感じ, 絆を求め ていたり, 自分の言葉が出ないと自覚しても, 多忙な 様子の看護師を見て, 話すことを止めている患者がい ることも報告されている7),10)。そのため, 看護師は見 当識障害や会話の障害など, せん妄患者によく認めら れる現象が，患者にとってどれほど苦痛で辛いものか を認識する必要がある。せん妄を発症している患者に 対して, 看護師側が一方的に情報提供して現実的生活 感覚を維持させようとしても, 見当識が障害され, 言 葉が出せない患者にとっては, 逆に苦痛を与えること にもなりかねない。患者が今, 何を感じ, 何を思って いるのかを考えて看護を行う必要がある。

せん妄発症後, 本症例のようにせん妄の記憶や思い を持っているものの, 看護師や家族にさえ言えなかっ たり，言う機会がない患者も存在するかもしれない。 斉藤ら99は，せん妄を起こした体験を看護師に話した が否定され, その後は体験を話さなくなった患者や, 他者の幻覚体験を聞き自分だけではないと安心した患 者, 家族のみに話をしていた患者がいたことを報告し ている。

このような患者にとって, せん妄は辛い記憶であり, 重荷になっている可能性もあり支援の必要性が示唆さ れる。看護師は, せん妄を発症した患者の言葉や思い を表面的ではなく, 十分に共感し, ありのままに受け 止める必要がある。そして, せん妄が名誉を污すもの や恥ずべきものではないこと, たびたび起こる可能性 があることを伝える必要がある。このように対処する ためには, 親身に話を聞く態度や落ち着いた環境, 術 前からの信頼関係も重要であろう。

また, 患者にとって家族は, 現実を知覚する大事な 手段のひとつである。しかし, せん妄状態を呈してい る患者を見る家族も精神的なダメージを受け,「おか しくなってしまったのではないか？治らないのでは ないか? 」という不安を抱く。せん妄の多くは一時的 であることを患者の家族にも伝え, 安心させる必要が ある。

\section{おわりに}

せん妄の原因や要因についてはわずかではあるが明 らかになってきており, 将来, 予防は可能かもしれな
い。しかし, その道のりは未だ長く, 一貫した手がか りすらないに等しい。本症例は一人の患者について述 べたものであり, 一般化はできない。しかし, せん妄 の記憶がある患者は, その経験を恥じるとともに, 辛 く感じていることを, 看護師は認識する必要がある。 そして, そのような患者の思いを知る努力こそが必要 ではないかと考える。

\section{文 献}

1) Truman B, Ely EW. Monitoring delirium in critically ill patients using the confusion assessment method for the intensive care unit. Crit Care Nurse. 2003;23:25-35.

2) 高橋三郎, 大野 裕, 染矢俊幸. せん妄, 認知症, 健忘性 障害, および他の認知障害. DSM- IV - TR 精神疾患の分類 と診断の手引き. 東京 : 医学書院；2006. p. 73.

3) 池松裕子. 精神 . 心理の観察項目. 早わかり看護観察アセ スメントノート。東京：照林社；2006. p. 60-70.

4) Cole MG, Primeau F, McCusker J. Effectiveness of interventions to prevent delirium in hospitalized patients: a systematic review. CMAJ. 1996;155:1263-343.

5) Milisen K, Foreman MD, Abraham IL, et al. A nurse-led interdisciplinary intervention program for delirium in elderly hip-fracture patients. J Am Geriatr Soc. 2001;49: 523-32.

6) Burns SM. Delirium during emergence from anesthesia: a case study. Crit Care Nurse. 2003;23:66-9.

7) Granberg A, Engberg IB, Lundberg D. Acute confusion and unreal experiences in intensive care patients in relation to the ICU syndrome. Part II. Intensive Crit Care Nurs. 1999;15:19-33.

8) Lof L, Berggren L, Ahlstrom G. Severely ill ICU patients recall of factual events and unreal experiences of hospital admission and ICU stay-3 and 12 months after discharge. Intensive Crit Care Nurs. 2006;22:154-66.

9) 斉藤静代, 白石裕子, 内海知子, 他. ICU体験内容の分析 からICU看護を考える一入室経験患者のインタビューか ら一。看護技術. 2005;51:62-6.

10) Laitinen H. Patients' experience of confusion in the intensive care unit following cardiac surgery. Intensive Crit Care Nurs. 1996;12:79-83.

11) 綿貫成明, 酒井郁子, 竹内登美子, 他. 日本語版 NEECHAM混乱・錯乱状態スケールの開発およびせん妄 のアセスメント. 臨看研進歩. 2001;12:46-63.

12) Trzepacz PT, Baker RW, Greenhouse J. A symptom rating scale for delirium. Psychiatry Res. 1988;23:89-97.

13) Inouye SK, van Dyck DH, Alessi CA, et al. Clarifying confusion: the confusion assessment method. A new method for detection of delirium. Ann Intern Med. 1990;113:941-8.

14) Neelon VJ, Champagne MT, Caplson JR, et al. The NEECHAM Confusion Scale: construction, validation, and clinical testing. Nurs Res. 1996;45:324-30.

15) Ely EW, Inouye SK, Bernard GR, et al. Delirium in mechanically ventilated patients: validity and reliability of the confusion assessment method for the intensive care unit (CAM-ICU). JAMA. 2001;286:2703-10.

16) Trzepacz PT, Mittal D, Torres R, et al. Validation of the Delirium Rating Scale-revised-98: comparison with the delirium rating scale and the cognitive test for delirium. J Neuropsychiatry Clin Neurosci. 2001;13:229-42. 
17) 稲本 俊, 小谷なつ恵, 萩原淳子, 他. 術後せん妄の発症 状況とそれに対する看護ケアについての臨床的研究. 京大 医療技短大紀. 2001;21:11-23.

18) 綿貫早美, 狩野太郎, 亀山絹代. 高齢手術患者の術後せん 妄発症率と発症状況の分析に関する研究. 群馬保健紀. 2002;23:109-16.
19) 児島敦子, 武田則昭, 石川 元, 他. 心蔵手術患者におけ る術後せん妄の発現の危険因子に関する研究. 臨精医. 1999;28:575-83.

20) 雄西智恵美. 術後せん妄, 成人看護学周手術期看護論. 雄 西智恵美, 秋元典子編. 東京：ヌーヴェルヒロカワ; 2007. p. 196-204.

\title{
Abstract \\ A case of cardiac surgery patient who expressed distress about delirium in the ICU
}

\author{
Harumi Ejiri
}

Kamo Nursing College

654-1 Ibobara, Josui-cho, Toyota, Aichi 471-8505, Japan

Delirium is an impairment of cognitive function manifesting a lack of concentration, disturbance of consciousness, and alteration of sleep wake cycle, which occurs an abrupt onset and develops within a relatively brief duration. This report describes the patient's perception about experience of delirium in the ICU. A patient in the early sixty underwent a surgery for left side atrioventricular valve replacement and maze procedure. On postoperative day 2, he exhibited pessimistic attitude, resistance and refusal to medical treatment, and disorientation of day and time. Only his family visitation was able to let him recognize real world and feel secure. After recovering from delirium, on postoperative day 8 , he said "I am so sorry that I was disgraceful shape when I stayed in the ICU" with tears running. This case illustrates that the experience of delirium seriously distress the patients. It is recommended that nursing staff caring for patients with delirium need to understand such patient suffering.

Key words: (1) delirium, (2) distress, (3) nursing

J Jpn Soc Intensive Care Med. 2008;15:543 547. 